Article

\title{
Life-Cycle Assessment of an Innovative Ground-Source Heat Pump System with Upstream Thermal Storage
}

\author{
Emanuele Bonamente 1,2,* (D) and Andrea Aquino ${ }^{2}$ \\ 1 Department of Engineering, University of Perugia, 06125 Perugia, Italy \\ 2 Interuniversity Research Center on Pollution and Environment, University of Perugia, 06125 Perugia, Italy; \\ aquino@crbnet.it \\ * Correspondence: emanuele.bonamente@unipg.it; Tel.: +39-075-585-3914
}

Received: 30 September 2017; Accepted: 10 November 2017; Published: 13 November 2017

\begin{abstract}
An innovative space-conditioning system is proposed and a life-cycle assessment (LCA) is presented. The layout is obtained starting from a ground-source heat pump system (GSHP) and includes upstream thermal storage (TS). A prototype of the system, implemented following this new approach, is currently in use for space heating and cooling of an industrial building. As a result of the TS designed to decouple the geothermal side from the heat-pump side, the system is able to provide the required thermal energy to the building with a reduced-size geothermal installation (i.e., shorter/fewer boreholes (BHs)). The performance was monitored for over 2 years, both in cooling and heating modes. A LCA study of this system is performed on the basis of specific data for implementation and operation phases. The results are given in terms of the comprehensive ReCiPe midpoint and endpoint indicator suite and are compared with literature studies of other conventional technologies for space conditioning.
\end{abstract}

Keywords: ground-source heat pump; thermal storage; life-cycle assessment (LCA); geothermal energy

\section{Introduction}

In recent years, the European Commission has set new targets for the emission of greenhouse gases (GHGs) by the building sector, with the goal of reducing the emissions of equivalent $\mathrm{CO}_{2}\left(\mathrm{CO}_{2} \mathrm{eq}\right)$ by $90 \%$ by the year 2050 [1]. As reported in the 2014/2015 European Work Program, more than 17\% of the primary energy saving potential of the European Union (EU) for 2050 [2] is related to building retrofit. This would correspond to retrofitting $80 \%$ of the 25 billion square meters of the current floor space in EU-27, Switzerland and Norway [3]. As a building is characterized by a continuous use of energy and raw materials during its entire life cycle, a major energy use in situ is necessary for the operation phase (i.e., use of the building), while minor energy consumption is due to construction, operation, retrofit and demolition stages, and, indirectly, for the production of building materials and technical installations [4]. Considering that, on average, up to $60 \%$ of the energy consumption is due to space conditioning, building energy efficiency (both in the case of new construction and retrofitting) represents a key strategy, particularly where, as in the Italian case, the majority of residential and commercial buildings were built before strict regulations on energy efficiency were enforced [5]. As reported in recent national studies [6], total annual energy saving potentials of approximately 50 and $17.3 \mathrm{GWh} /$ year are achievable (from 2014 to 2020) from the retrofitting of existent residential and non-residential buildings, respectively.

Integrated renewable-energy systems represent the most effective solution in mitigating the environmental impacts of buildings [7]. Among the available renewable energy systems for airconditioning [8], ground-source heat pump systems (GSHPs) are based on the indirect use of 
low-temperature geothermal sources; they exchange heat with the ground via geothermal boreholes (BHs) [9] and are easily suitable for buildings. Compared to power generation systems and direct heating systems, the feasibility of indirect heating systems is not influenced by the presence of the geothermal resource at the site; the thermal energy exploitation of a GSHP, as a result of the low operative temperatures involved, is limited to the first surface layer of the ground [10].

According to the European Directive 28/2009, the output energy produced by a heat pump (HP) system can be considered as renewable energy only if it significantly exceeds the total amount of input energy [11]. In other words, a HP system is defined as renewable energy system according to the measured coefficient of performance (COP). Nevertheless, the exploitation of geothermal energy is affected by many sustainability implications [12]. In particular, the design of a GSHP should take into account several environmental negative impacts, such as the risks of contamination of shallow aquifers and other water bodies, the soil compaction, and habitat loss or disturbance. All these environmental issues are strictly related to drilling activities, which also sensibly affect the initial costs by up to $50 \%$ of the total [13]. One of the most effective technological enhancements of current heating, ventilation, and air-conditioning (HVAC) systems is the recourse to heat storage devices (i.e., thermal energy storage-TES), which allows for the optimization of the operational performance, making it possible to accumulate thermal energy (both heat and/or cold) when renewable sources are available and to use this upon demand. The innovation proposed in this work is the inclusion of heat storage in the standard layout of a GSHP to simultaneously reduce the negative impact on the environment and the initial costs of these systems [14]. A further improvement of the prototype has already been proposed, replacing the sensible-heat thermal storage (TS) with a latent-heat TS made of phase-change materials (PCM) [15].

Life-cycle assessment (LCA) is a strategic asset to measure the potential environmental impact of a product and/or service throughout its life (i.e., cradle to grave) from raw material acquisition to processing, manufacturing, use, and finally its disposal $[16,17]$. Furthermore, LCA can be used to guide the design phase towards the most energy-efficient and environmentally efficient option [17-19], comparing the performance of different products or technologies that provide the same service. As a first step of a LCA analysis, the product is described, and all the specifications necessary to build the life-cycle inventory (LCI) are defined (e.g., the functional unit, the system's spatial and time boundaries, quality criteria, etc.). The LCI is the resume of all the measurements and information on matter and energy flows collected for each stage of the product's life cycle. The environmental impact is assessed from the LCI results, and it is described by the relevant environmental indicators (carbon footprint, renewable energy use, soil consumption, etc.). The LCA also includes the identification of significant issues and the evaluation of results.

The aim of the present work is to use the LCA to measure the environmental impact of an innovative GSHP for a commercial building, located in central Italy, and compare it with different system configurations and operative modes. The energy performance of the existent prototype was continuously monitored with a custom data acquisition system. In particular, this analysis focuses on the energy consumption of the system in heating and cooling mode, which was monitored over 1 year from October 2013 to September 2014.

\section{Materials and Methods}

\subsection{Case-Study Description}

The analyzed air-conditioning system was realized within the SCER project [20] (the Italian acronym for Development of Renewable-Energy Air-Conditioning Systems), an Italian research project aimed at increasing the production of renewable energy for the air-conditioning of commercial buildings, with high efficiency heating and cooling systems based on a mix of renewable energy sources. The SCER project produced two air-conditioning pilot systems: a woodchip boiler coupled with an absorption chiller [21] and a GSHP coupled with an underground TS device (i.e., in the case of 
the study); both the systems are connected to a photovoltaic field. The present work investigates the environmental sustainability of the GSHP prototype. In the investigated buildings there are different conditioned spaces: two locker rooms $\left(28\right.$ and $\left.27 \mathrm{~m}^{2}\right)$ and five offices $\left(28,14,20,27\right.$, and $\left.14 \mathrm{~m}^{2}\right)$ for a total air-conditioned surface of approximately $158 \mathrm{~m}^{2}$. Before the energy retrofit, air-to-air HPs were used for the air-conditioning of the offices and electric heaters were used for the locker rooms. The layout of the GSHP prototype includes three $120 \mathrm{~m}$ deep BHs, underground TS (i.e., a quasi-cubic concrete tank filled with $12.5 \mathrm{~m}^{3}$ of water), a reversible $\mathrm{HP}(17 \mathrm{~kW})$, and a distribution system with fan-coil units.

The prototype is designed to work both in conventional mode (Figure 1) and in alternative mode (Figure 2). The conventional mode represents the usual way of implementing and operating a GSHP. The size of the HP (i.e., $\mathrm{kW}_{\text {th }}$ ) is chosen in order to cover the peaks of heating and cooling energy demand during the year, and the geothermal field is sized to match such peaks. Given the specific thermal yield of the implementation site (i.e., $\mathrm{kW} / \mathrm{m}$ ), the number and length of the $\mathrm{BHs}$ are computed. In our study, a total exchange length of $360 \mathrm{~m}$ (three $120 \mathrm{~m} \mathrm{BHs)}$ is required, considering a thermal yield slightly lower than $50 \mathrm{~W} / \mathrm{m}$. In this case, the plat sizing is performed using a power-peak approach.

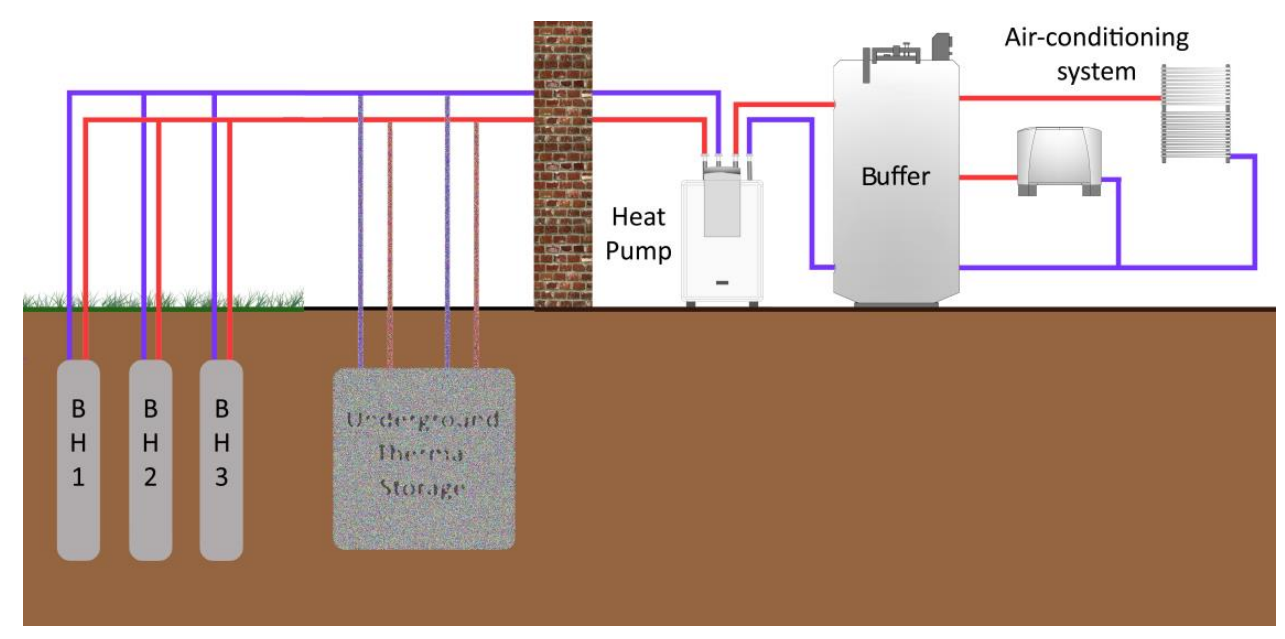

Figure 1. The prototype layout: conventional mode.

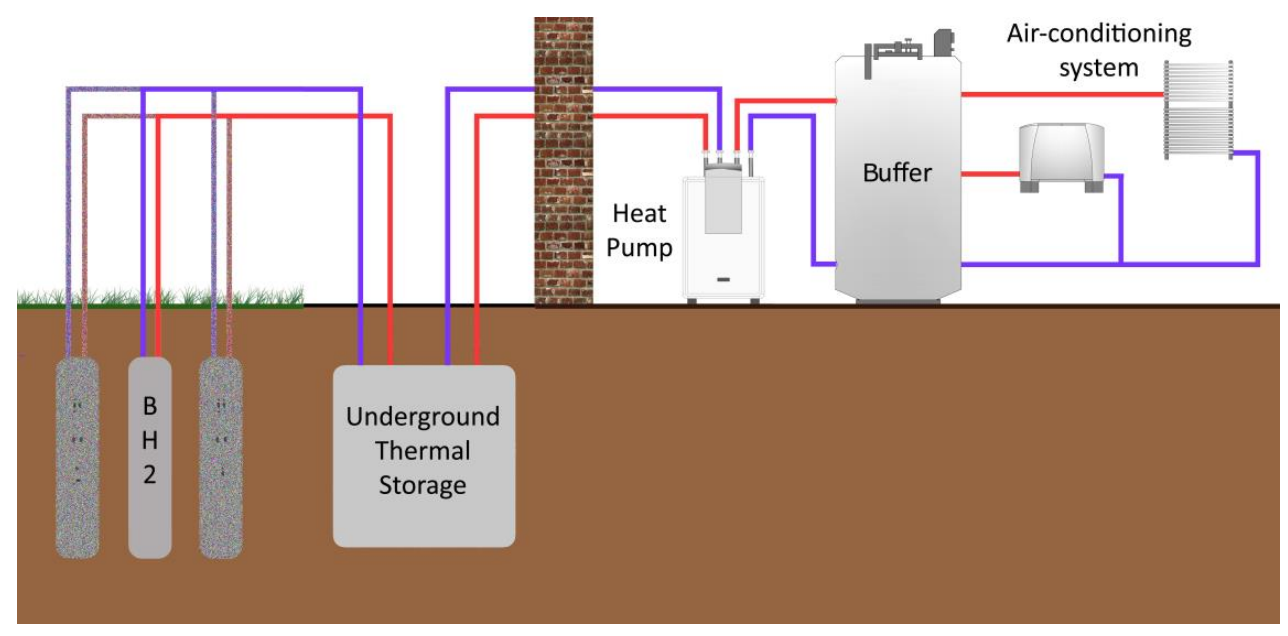

Figure 2. The prototype layout: alternative mode.

The alternative mode represents an evolution of the conventional approach, in which the system sizing is performed considering the daily energy demand rather than the peak power. Once the maximum daily energy is estimated (i.e., $\mathrm{kWh}_{\text {th }}$ required during the coldest/hottest days of the year), 
the geothermal field sizing (i.e., total exchange length) is found considering the average power required to exchange it with the ground during a $24 \mathrm{~h}$ period. Reduced-size geothermal BHs charge the TS working with a duty cycle up to $100 \%$; the HP takes energy only upon request. In this operation mode, the building energy demand is covered using the underground TS and only one $120 \mathrm{~m} \mathrm{BH}$.

For both modes, a custom data acquisition system allows for testing the prototype performance under real working conditions. For safety and reversibility reasons, two cylindrical heat exchangers (Figure 3a,b) are placed within the underground tank (Figure 3c) to avoid the mixing of the storage fluid (i.e., water) and the heat transfer fluid (i.e., water and propylene glycol). The TS can be bypassed to switch the system to the conventional mode. The heat exchangers are grouped in two units connected to the HP and BH loops. Each unit is formed by an energy exchange surface of approximately $20 \mathrm{~m}^{2}$.

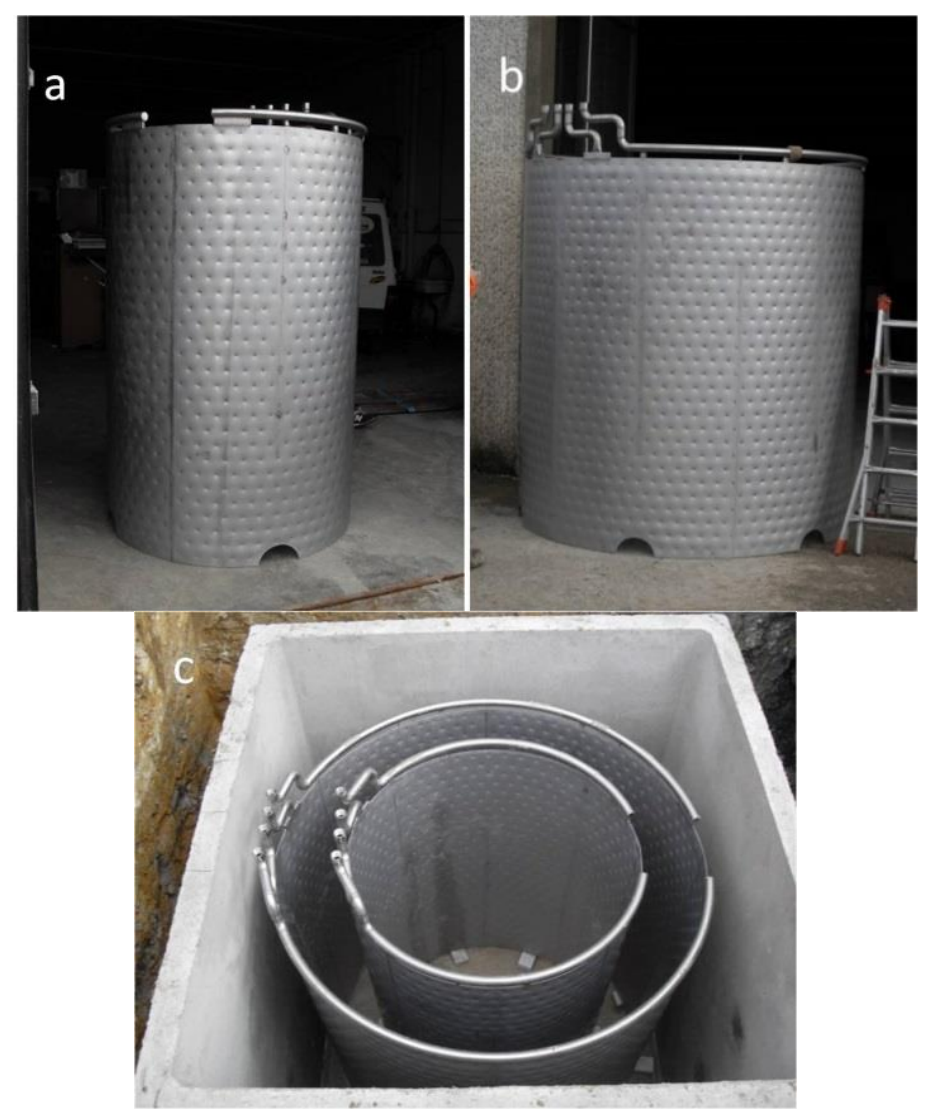

Figure 3. The cylindrical heat exchangers: (a) inside exchangers; (b) outside exchangers; (c) view of the heat exchanger assembly within the thermal storage.

\subsection{Goal of the Analysis}

The present LCA, following the methodology regulated by the ISO 14044 [15] and 14040 [17] international standards, is dedicated to the evaluation of the environmental sustainability of the TES GSHP prototype considering impacts from the infrastructure construction and assembly and from energy consumption during the use phase on an annual basis. The system lifetime is conservatively estimated to be 20 years, and impacts from infrastructures and machineries are allocated using this time period. The environmental impact of the GSHP prototype is evaluated for three cases: a baseline scenario was set up considering the conventional layout (three BHs and no TS); a storage scenario included the underground TES coupled with a single $\mathrm{BH}$; an improved scenario was set up considering a potential system upgrade where heat exchangers are removed [15]. A fourth scenario, derived from the same previous work [15], was also used for a comparison of the final results and showing the 
potential of the system. In this case (i.e., the optimal scenario), more efficient circulating pumps and energy from photovoltaic panels were used.

It is important to consider that the performance of both the baseline and storage scenarios were measured using the working prototype presented in Section 2.1, while the improved scenario is a proposed upgrade of the system, the performance of which was obtained using validated computational fluyd dynamics (CFD) simulations. A schematic view of the prototype layout and the system boundaries is given in Table 1. As shown in the following sections, each scenario is characterized by a specific COP for heating and cooling modes and a different incidence of materials for infrastructures. The COP of the baseline and the storage scenario has been directly computed from measured data; the COP of the improved scenario has been computed using the simulated temperature of the water to the HP (i.e., $\mathrm{T}_{\text {inlet }}$ ) and by considering the characteristic COP versus $\mathrm{T}_{\text {inlet }}$ curve of the HP itself.

The LCA, performed with SimaPro v8.2.3 software (Pré Consultants B.V., Amersfoort, The Netherlands), refers to a period of 1 year, considering both heating and cooling modes. The life-cycle model for the baseline scenario includes four phases (BHs, HP, heating consumption, and cooling consumption); the storage and improved scenarios include five phases (BHs, TS, HP, heating consumption, and cooling consumption). The indoor distribution system is not considered. The system boundaries include the production of raw materials, the prototype construction, and the use stage.

The functional unit has been set as $1 \mathrm{kWh}$ of thermal energy provided to (or subtracted from) the building.

\subsection{Life-Cycle Inventory}

The primary data necessary to build the LCI were directly measured from on-site monitoring of the prototype, including materials and the annual energy consumption in the heating and cooling modes. Where necessary, the on-site measurements were integrated with technical datasheets, scientific references, and simulated data from previous works. The Ecoinvent database 3.2 was used to obtain the data related to the raw material supply and equipment transport and manufacturing [22]. No cut-off rule was used. The raw materials were classified within three groups: BHs (materials used to build the geothermal heat exchangers and piping), TS (materials used to realize the underground TES system, including, in the storage scenario, the cylindrical heat exchangers), and HPs (the HP and all the hydraulic connections within the technical room). The materials incidence and the construction processes are detailed in Table 1.

Table 1. The materials incidence of the analyzed scenarios.

\begin{tabular}{|c|c|c|c|c|c|c|c|c|}
\hline & \multicolumn{2}{|c|}{ Baseline } & \multicolumn{3}{|c|}{ Storage } & \multicolumn{3}{|c|}{ Improved } \\
\hline Material & Boreholes & Heat Pump & Boreholes & $\begin{array}{l}\text { Thermal } \\
\text { Storage }\end{array}$ & $\begin{array}{l}\text { Heat } \\
\text { Pump }\end{array}$ & Boreholes & $\begin{array}{l}\text { Thermal } \\
\text { Storage }\end{array}$ & $\begin{array}{l}\text { Heat } \\
\text { Pump }\end{array}$ \\
\hline $\begin{array}{c}\text { High-density } \\
\text { polyethilene }(\mathrm{kg})\end{array}$ & 428.14 & - & 140.02 & 9.57 & - & 140.02 & 7.57 & - \\
\hline Sand $(\mathrm{kg})$ & 40,526 & - & 10,120 & 10,189 & - & 10,120 & 10,189 & - \\
\hline Gravel (kg) & 53,606 & - & 13,398 & 13,440 & - & 13,398 & 13,440 & - \\
\hline Excavation $\left(\mathrm{m}^{3}\right)$ & 55.93 & - & 13.98 & 76.37 & - & 13,98 & 76.37 & - \\
\hline Water $(\mathrm{kg})$ & 583.29 & - & 190.76 & 3510 & - & 190.76 & 3510 & - \\
\hline Propilene glycol (kg) & 257.98 & - & 84.37 & 4.56 & - & 84.37 & 4.56 & - \\
\hline Concrete $\left(\mathrm{m}^{3}\right)$ & 3.63 & - & 1.21 & 1.58 & - & 1.21 & 1.58 & - \\
\hline Reinforcement steel (kg) & 104.45 & - & 43 & 64 & - & 43 & 43 & - \\
\hline Brass (kg) & - & 6 & - & 8 & - & - & - & - \\
\hline Power $(\mathrm{kW})$ & - & 17 & - & - & 17 & - & - & 17 \\
\hline Steel $(\mathrm{kg})$ & - & 81 & - & 361.64 & 81 & - & - & 81 \\
\hline Tube insulation (kg) & - & 21.76 & - & - & 27.76 & - & - & 27.76 \\
\hline Aluminum tape $\left(\mathrm{m}^{2}\right)$ & - & 10 & - & - & 10 & - & - & 10 \\
\hline
\end{tabular}


Measured data for electric energy consumption and thermal energy production are reported in Error! Not a valid bookmark self-reference. During the working period, the prototype switched between the conventional and the alternative mode, allowing for the calculation of the COP related to the storage and baseline scenarios. The COP for the improved scenario was calculated using CFD simulations validated against the measured date [15]. The annual thermal energy required by the building for each scenario was set at the value measured in Table 2. The electric energy consumption was computed for each scenario using the appropriate COP, as proposed in Table 3. Such values were used as inputs for the LCA model.

Table 2. Data from system monitoring.

\begin{tabular}{|c|c|c|c|c|}
\hline \multicolumn{2}{|c|}{ Time Intervals } & \multirow{2}{*}{ Operation Mode } & \multirow{2}{*}{ Electric Energy (kWh) } & \multirow{2}{*}{ Thermal Energy (kWh) } \\
\hline Start & Stop & & & \\
\hline $11 / 10 / 2013$ & $27 / 11 / 2013$ & Alternative & 1203.26 & 3441.33 \\
\hline $28 / 11 / 2013$ & $06 / 12 / 2013$ & Conventional & 346.00 & 1211.00 \\
\hline $07 / 12 / 2013$ & $16 / 12 / 2013$ & Alternative & 575.00 & 1644.50 \\
\hline $17 / 12 / 2013$ & $15 / 01 / 2014$ & Alternative & 1595.00 & 4561.70 \\
\hline $16 / 01 / 2014$ & $26 / 03 / 2014$ & Alternative & 3184.00 & 9106.24 \\
\hline- & - & - & Heating Total & $19,964.77$ \\
\hline $13 / 06 / 2014$ & $26 / 06 / 2014$ & Conventional & 71.11 & 284.42 \\
\hline $27 / 06 / 2014$ & $31 / 07 / 2014$ & Conventional & 554.00 & 2216.00 \\
\hline $01 / 08 / 2014$ & $29 / 08 / 2014$ & Alternative & 563.00 & 1790.34 \\
\hline $30 / 08 / 2014$ & $17 / 09 / 2014$ & Alternative & 197.35 & 627.59 \\
\hline- & - & - & Cooling Total & 4918.3 \\
\hline
\end{tabular}

Table 3. Thermal and electric energy consumptions used for the life-cycle assessment (LCA).

\begin{tabular}{ccccccc}
\hline Scenario & \multicolumn{3}{c}{ Heating } & \multicolumn{3}{c}{ Cooling } \\
\cline { 2 - 7 } & $\begin{array}{c}\text { Thermal Energy } \\
\mathbf{( k W h )}\end{array}$ & COP & $\begin{array}{c}\text { Electric Energy } \\
\mathbf{( k W h )}\end{array}$ & $\begin{array}{c}\text { Thermal Energy } \\
\mathbf{( k W h )}\end{array}$ & COP & $\begin{array}{c}\text { Electric Energy } \\
\mathbf{( k W h )}\end{array}$ \\
\hline Baseline & $19,964.77$ & 3.50 & 5704.22 & 4918.35 & 4.00 & 1229.59 \\
Storage & $19,964.77$ & 2.86 & 6980.69 & 4918.35 & 3.18 & 1546.65 \\
Improved & $19,964.77$ & 3.39 & 5889.31 & 4918.35 & 3.41 & 1442.33 \\
\hline
\end{tabular}

\subsection{Impact Assessment Methodology}

Each scenario was analyzed by the ReCiPe 2008 method [22], which uses 18 impact categories addressed at the midpoint level and further converts and aggregates into three endpoint categories.

Midpoint level indicators are direct measurements of the impacts arising from the considered phenomena. A total of 18 physical quantities were computed from the LCI results, providing a quantitative description of the single drivers of the environmental impact associated with the study. These include soil acidification (measured in $\mathrm{kg} \mathrm{SO}_{2} \mathrm{eq}$ ), the emission of $\mathrm{GHGs}$ (measured in $\mathrm{kg} \mathrm{CO}_{2} \mathrm{eq}$ ), water depletion (measured in $\mathrm{m}^{3} \mathrm{H}_{2} \mathrm{O}$ ), and so forth.

Impact categories at the endpoint level represent the areas in which the damages of the midpoint phenomena were observed. They are used to make clearer and more easily readable the results of the life-cycle impact assessment (LCIA), aggregating the midpoint indicators into three higher categories: resources, ecosystems, and human health. Endpoint categories are measured in points (i.e., they are not physical quantities) and should be used primarily for comparative studies. These three categories form the basis for decisions in policy and sustainable development. The default hierarchist version was used in this study. 


\section{Results and Discussion}

According the measured environmental indicators, energy consumption was by large the most impacting process, with the only exceptions being ozone depletion and metal depletion, which were mainly due to the HP and HP plus storage, respectively. Energy consumption being determined by the system's COP, the latter was the parameter to which the results were the most sensitive.

The baseline scenario is characterized by a lower environmental impact than the storage scenario (Tables 4 and 5). This is due to the different energy consumption produced by the different COP of the two systems. Even if the storage scenario shows smaller impacts associated to one $\mathrm{BH}$ and the storage (i.e., $199.2 \mathrm{~kg} \mathrm{CO}_{2}$ eq) than the baseline scenario (255.6 $\mathrm{kg} \mathrm{CO}_{2} \mathrm{eq}$ for three $\mathrm{BHs}$ ), the COP of the storage scenario is worse than that of the baseline scenario. In fact, when the system works in alternative mode, the cylindrical heat exchangers produce a thermal shift that reduces the system COP; while the system is still able to provide the required thermal energy to the building, the temperature of the brine entering the HP is lower, and the driving energy consumption increases, making this layout uncompetitive with respect to the conventional mode.

Table 4. Midpoint impact indicators of the baseline scenario.

\begin{tabular}{|c|c|c|c|c|c|c|}
\hline \multicolumn{7}{|c|}{ Baseline Scenario } \\
\hline \multirow{2}{*}{$\begin{array}{l}\text { Impact Category } \\
\text { Climate change }\end{array}$} & \multicolumn{2}{|c|}{ Total } & \multirow{2}{*}{$\begin{array}{c}\text { Boreholes } \\
5.8 \%\end{array}$} & \multirow{2}{*}{$\begin{array}{c}\text { Heat Pump } \\
4.6 \%\end{array}$} & \multirow{2}{*}{$\begin{array}{c}\text { Heating } \\
73.7 \%\end{array}$} & \multirow{2}{*}{$\begin{array}{c}\text { Cooling } \\
15.9 \%\end{array}$} \\
\hline & 3889.14 & $\mathrm{~kg} \mathrm{CO}_{2} \mathrm{eq}$ & & & & \\
\hline Ozone depletion & 0.00280 & kg CFC-11eq & $1.3 \%$ & $82.5 \%$ & $13.3 \%$ & $2.9 \%$ \\
\hline Terrestrial acidifications & 16.23 & $\mathrm{~kg} \mathrm{SO}_{2} \mathrm{eq}$ & $6.3 \%$ & $5.3 \%$ & $72.7 \%$ & $15.7 \%$ \\
\hline Freshwater eutrophication & 1.25 & $\mathrm{~kg}$ Peq & $5.9 \%$ & $12.5 \%$ & $67.1 \%$ & $14.5 \%$ \\
\hline Marine eutrophication & 0.76 & $\mathrm{~kg} \mathrm{Neq}$ & $6.0 \%$ & $5.9 \%$ & $72.5 \%$ & $15.6 \%$ \\
\hline Human toxicity & 1356.61 & kg 1,4-DBeq & $7.8 \%$ & $23.7 \%$ & $56.3 \%$ & $12.1 \%$ \\
\hline Photochemical oxidant formation & 9.15 & kg NMVOC & $11.3 \%$ & $3.9 \%$ & $69.7 \%$ & $15.0 \%$ \\
\hline Particulate matter formation & 5.82 & kg PM10eq & $9.1 \%$ & $7.1 \%$ & $69.0 \%$ & $14.9 \%$ \\
\hline Terrestrial ecotoxicity & 0.78 & kg 1,4-DBeq & $5.1 \%$ & $3.1 \%$ & $75.6 \%$ & $16.3 \%$ \\
\hline Freshwater ecotoxicity & 151.45 & kg 1,4-DBeq & $1.9 \%$ & $4.6 \%$ & $76.9 \%$ & $16.6 \%$ \\
\hline Marine ecotoxicity & 134.03 & kg 1,4-DBeq & $2.2 \%$ & $5.4 \%$ & $76.0 \%$ & $16.4 \%$ \\
\hline Ionising radiation & 548.22 & $\mathrm{kBq} U 235 \mathrm{eq}$ & $3.3 \%$ & $1.2 \%$ & $78.6 \%$ & $16.9 \%$ \\
\hline Agricultural land occupation & 270.10 & $\mathrm{~m}^{2} \mathrm{a}$ & $2.4 \%$ & $2.0 \%$ & $78.6 \%$ & $16.9 \%$ \\
\hline Urban land occupation & 32.88 & $\mathrm{~m}^{2} \mathrm{a}$ & $17.4 \%$ & $4.0 \%$ & $64.7 \%$ & $13.9 \%$ \\
\hline Natural land transformation & 0.62 & $\mathrm{~m}^{2}$ & $14.0 \%$ & $2.0 \%$ & $69.0 \%$ & $14.9 \%$ \\
\hline Water depletion & 61.24 & $\mathrm{~m}^{3}$ & $11.3 \%$ & $2.1 \%$ & $71.2 \%$ & $15.4 \%$ \\
\hline Metal depletion & 291.93 & $\mathrm{~kg}$ Feeq & $9.1 \%$ & $43.5 \%$ & $39.0 \%$ & $8.4 \%$ \\
\hline Fossil depletion & 1142.02 & $\mathrm{~kg}$ oileq & $7.8 \%$ & $1.9 \%$ & $74.3 \%$ & $16.0 \%$ \\
\hline
\end{tabular}

Table 5. Midpoint impact indicators for storage scenario.

\begin{tabular}{|c|c|c|c|c|c|c|c|}
\hline \multicolumn{8}{|c|}{ Storage Scenario } \\
\hline Impact Category & & tal & Boreholes & Storage & $\begin{array}{l}\text { Heat } \\
\text { Pump }\end{array}$ & Heating & Cooling \\
\hline Climate change & 4664.23 & $\mathrm{~kg} \mathrm{CO} \mathrm{CO}_{2}$ & $1.47 \%$ & $2.80 \%$ & $3.83 \%$ & $75.23 \%$ & $16.67 \%$ \\
\hline Ozone depletion & 0.00289 & kg CFC-11eq & $0.00 \%$ & $0.36 \%$ & $79.98 \%$ & $15.80 \%$ & $3.50 \%$ \\
\hline Terrestrial acidifications & 19.52 & $\mathrm{~kg} \mathrm{SO}_{2} \mathrm{eq}$ & $0.01 \%$ & $3.79 \%$ & $4.41 \%$ & $73.96 \%$ & $16.39 \%$ \\
\hline Freshwater eutrophication & 1.50 & $\mathrm{~kg}$ Peq & $0.00 \%$ & $4.30 \%$ & $10.50 \%$ & $68.74 \%$ & $15.23 \%$ \\
\hline Marine eutrophication & 0.91 & $\mathrm{~kg} \mathrm{Neq}$ & $0.00 \%$ & $3.42 \%$ & $4.91 \%$ & $73.94 \%$ & $16.38 \%$ \\
\hline Human toxicity & 1592.80 & kg 1,4-DBeq & $0.48 \%$ & $6.68 \%$ & $20.20 \%$ & $58.71 \%$ & $13.01 \%$ \\
\hline Photochemical oxidant formation & 10.75 & kg NMVOC & $0.01 \%$ & $5.19 \%$ & $3.35 \%$ & $72.57 \%$ & $16.08 \%$ \\
\hline Particulate matter formation & 7.18 & kg PM10eq & $0.00 \%$ & $8.49 \%$ & $5.72 \%$ & $68.49 \%$ & $15.17 \%$ \\
\hline Terrestrial ecotoxicity & 0.95 & kg 1,4-DBeq & $0.00 \%$ & $2.47 \%$ & $2.55 \%$ & $76.78 \%$ & $17.01 \%$ \\
\hline Freshwater ecotoxicity & 189.89 & kg 1,4-DBeq & $0.02 \%$ & $4.23 \%$ & $3.65 \%$ & $75.11 \%$ & $16.64 \%$ \\
\hline Marine ecotoxicity & 168.52 & kg 1,4-DBeq & $0.02 \%$ & $4.89 \%$ & $4.30 \%$ & $73.99 \%$ & $16.39 \%$ \\
\hline Ionising radiation & 664.26 & kBq U235eq & $0.11 \%$ & $1.26 \%$ & $1.00 \%$ & $79.36 \%$ & $17.58 \%$ \\
\hline Agricultural land occupation & 331.70 & $\mathrm{~m}^{2} \mathrm{a}$ & $0.04 \%$ & $2.11 \%$ & $1.63 \%$ & $78.33 \%$ & $17.35 \%$ \\
\hline Urban land occupation & 37.74 & $\mathrm{~m}^{2} \mathrm{a}$ & $0.03 \%$ & $8.22 \%$ & $3.49 \%$ & $68.93 \%$ & $15.27 \%$ \\
\hline Natural land transformation & 0.71 & $\mathrm{~m}^{2}$ & $0.00 \%$ & $4.25 \%$ & $1.79 \%$ & $74.25 \%$ & $16.45 \%$ \\
\hline Water depletion & 71.02 & $\mathrm{~m}^{3}$ & $0.04 \%$ & $3.60 \%$ & $1.83 \%$ & $75.16 \%$ & $16.65 \%$ \\
\hline Metal depletion & 566.98 & $\mathrm{~kg}$ Feeq & $0.15 \%$ & $46.37 \%$ & $22.38 \%$ & $24.57 \%$ & $5.44 \%$ \\
\hline Fossil depletion & 1348.68 & $\mathrm{~kg}$ oileq & $0.59 \%$ & $2.32 \%$ & $1.63 \%$ & $76.97 \%$ & $17.05 \%$ \\
\hline
\end{tabular}


When the cylindrical heat exchangers are removed, a sensible increase of the COP is expected (Table 3), according to the technical specifications of the HP, which show an increasing COP as the HP inlet temperature increases. The environmental impact of the improved scenario improves, and it becomes consistent with that of the baseline scenario (Table 6). To highlight the relation between the energy performance and environmental impact, the midpoint indicators are also shown per unit of produced thermal energy in Table 7. The improved scenario of the present work uses the same electric auxiliary devices of the storage scenario, which is oversized when the cylindrical exchangers are removed and only one BH is used. As reported in a previous analysis [15], an optimal scenario could be foreseen, providing a complete upgrade of the existing prototype by removing the cylindrical exchangers and using a smaller circulating pump. This produces a sensible increase of the system COP: 4.28 for the heating mode and 6.00 for the cooling mode. Furthermore, a market application of this system could easily be coupled with a photovoltaic plant to cover the electric energy demand. The environmental impact of the optimal scenario showed an average decrease of approximately $60 \%$ with respect to the baseline scenario. The endpoint indicators of all the analyzed scenarios are reported in Figure 4, where conventional HP systems are considered for comparison.

Table 6. Midpoint impact indicators for the improved scenario.

\begin{tabular}{|c|c|c|c|c|c|c|c|}
\hline \multicolumn{8}{|c|}{ Improved Scenario } \\
\hline Impact Category & \multicolumn{2}{|c|}{ Total } & $\begin{array}{c}\text { Boreholes } \\
1.72 \%\end{array}$ & $\begin{array}{c}\text { Storage } \\
1.16 \%\end{array}$ & $\begin{array}{c}\begin{array}{c}\text { Heat } \\
\text { Pump }\end{array} \\
4.50 \%\end{array}$ & $\begin{array}{l}\text { Heating } \\
74.40 \%\end{array}$ & $\begin{array}{c}\text { Cooling } \\
18.22 \%\end{array}$ \\
\hline Ozone depletion & 0.00281 & kg CFC-11eq & $0.37 \%$ & $0.16 \%$ & $82.38 \%$ & $13.73 \%$ & $3.36 \%$ \\
\hline Terrestrial acidifications & 16.51 & $\mathrm{~kg} \mathrm{SO}_{2} \mathrm{eq}$ & $1.73 \%$ & $1.25 \%$ & $5.21 \%$ & $73.75 \%$ & $18.06 \%$ \\
\hline Freshwater eutrophication & 1.26 & kg Peq & $1.44 \%$ & $0.95 \%$ & $12.40 \%$ & $68.44 \%$ & $16.76 \%$ \\
\hline Photochemical oxidant formation & 9.09 & kg NMVOC & $3.32 \%$ & $2.51 \%$ & $3.97 \%$ & $72.46 \%$ & $17.74 \%$ \\
\hline Particulate matter formation & 5.84 & kg PM10eq & $2.61 \%$ & $2.04 \%$ & $7.03 \%$ & $70.95 \%$ & $17.38 \%$ \\
\hline Terrestrial ecotoxicity & 0.80 & kg 1,4-DBeq & $1.38 \%$ & $0.81 \%$ & $3.00 \%$ & $76.16 \%$ & $18.65 \%$ \\
\hline Freshwater ecotoxicity & 157.92 & kg 1,4-DBeq & $0.45 \%$ & $0.31 \%$ & $4.39 \%$ & $76.19 \%$ & $18.66 \%$ \\
\hline Marine ecotoxicity & 139.41 & kg 1,4-DBeq & $0.52 \%$ & $0.36 \%$ & $5.19 \%$ & $75.45 \%$ & $18.48 \%$ \\
\hline Ionising radiation & 568.81 & kBq U235eq & $0.93 \%$ & $0.57 \%$ & $1.17 \%$ & $78.19 \%$ & $19.15 \%$ \\
\hline Metal depletion & 288.46 & kg Feeq & $2.45 \%$ & $2.85 \%$ & $43.98 \%$ & $40.74 \%$ & $9.98 \%$ \\
\hline Fossil depletion & 1151.10 & $\mathrm{~kg}$ oileq & $2.38 \%$ & $1.00 \%$ & $1.91 \%$ & $76.08 \%$ & $18.63 \%$ \\
\hline
\end{tabular}

Table 7. Midpoint impact indicators per unit of thermal energy for the three scenarios.

\begin{tabular}{|c|c|c|c|c|}
\hline Impact Category & Unit & Baseline & Storage & Improved \\
\hline Climate change & $\mathrm{kg} \mathrm{CO}_{2} \mathrm{eq} / \mathrm{kWh}_{\mathrm{th}}$ & 0.156 & 0.187 & 0.160 \\
\hline Ozone depletion & $\mathrm{kg} \mathrm{CFC-11eq/kWh}$ th & $1.13 \times 10^{-7}$ & $1.16 \times 10^{-7}$ & $1.13 \times 10^{-7}$ \\
\hline Terrestrial acidifications & $\mathrm{kg} \mathrm{SO}_{2} \mathrm{eq} / \mathrm{kWh}_{\mathrm{th}}$ & $6.52 \times 10^{-4}$ & $7.84 \times 10^{-4}$ & $6.63 \times 10^{-4}$ \\
\hline Freshwater eutrophication & $\mathrm{kg} P$ eq/kWh $\mathrm{kh}_{\mathrm{th}}$ & $5.02 \times 10^{-5}$ & $5.99 \times 10^{-5}$ & $5.08 \times 10^{-5}$ \\
\hline Marine eutrophication & $\mathrm{kg} \mathrm{Neq} / \mathrm{kWh}_{\mathrm{th}}$ & $3.07 \times 10^{-5}$ & $3.68 \times 10^{-5}$ & $3.13 \times 10^{-5}$ \\
\hline Human toxicity & $\mathrm{kg} 1,4-\mathrm{DBeq} / \mathrm{kWh}_{\text {th }}$ & $5.20 \times 10^{-2}$ & $6.40 \times 10^{-2}$ & $5.38 \times 10^{-2}$ \\
\hline Photochemical oxidant formation & $\mathrm{kg}$ NMVOC $/ \mathrm{kWh}_{\mathrm{th}}$ & $3.67 \times 10^{-4}$ & $4.32 \times 10^{-4}$ & $3.65 \times 10^{-4}$ \\
\hline Particulate matter formation & $\mathrm{kg} P M 10 \mathrm{eq} / \mathrm{kWh}_{\mathrm{th}}$ & $2.34 \times 10^{-4}$ & $2.88 \times 10^{-4}$ & $2.35 \times 10^{-4}$ \\
\hline Terrestrial ecotoxicity & $\mathrm{kg} 1,4-\mathrm{DBeq} / \mathrm{kWh}_{\mathrm{th}}$ & $3.17 \times 10^{-5}$ & $3.81 \times 10^{-5}$ & $3.24 \times 10^{-5}$ \\
\hline Freshwater ecotoxicity & $\mathrm{kg} 1,4$-DBeq $/ \mathrm{kWh}_{\mathrm{th}}$ & $6.10 \times 10^{-3}$ & $7.63 \times 10^{-3}$ & $6.34 \times 10^{-3}$ \\
\hline Marine ecotoxicity & $\mathrm{kg} 1,4-\mathrm{DBeq} / \mathrm{kWh}$ th & $5.40 \times 10^{-3}$ & $6.77 \times 10^{-3}$ & $5.60 \times 10^{-3}$ \\
\hline Ionising radiation & $\mathrm{kBq}$ U235eq/kWh & $2.20 \times 10^{-2}$ & $2.66 \times 10^{-2}$ & $2.28 \times 10^{-2}$ \\
\hline Agricultural land occupation & $\mathrm{m}^{2} \mathrm{a} / \mathrm{kWh}_{\mathrm{th}}$ & $1.08 \times 10^{-2}$ & $1.33 \times 10^{-2}$ & $1.13 \times 10^{-2}$ \\
\hline Urban land occupation & $\mathrm{m}^{2} \mathrm{a} / \mathrm{kWh}_{\mathrm{th}}$ & $1.32 \times 10^{-3}$ & $1.51 \times 10^{-3}$ & $1.27 \times 10^{-3}$ \\
\hline Natural land transformation & $\mathrm{m}^{2} / \mathrm{kWh}_{\mathrm{th}}$ & $2.50 \times 10^{-5}$ & $2.84 \times 10^{-5}$ & $2.45 \times 10^{-5}$ \\
\hline Water depletion & $\mathrm{m}^{3} / \mathrm{kWh}_{\mathrm{th}}$ & $2.46 \times 10^{-3}$ & $2.85 \times 10^{-3}$ & $2.45 \times 10^{-3}$ \\
\hline Metal depletion & $\mathrm{kg}$ Feeq $/ \mathrm{kWh}$ th & $1.17 \times 10^{-2}$ & $2.27 \times 10^{-2}$ & $1.16 \times 10^{-2}$ \\
\hline Fossil depletion & $\mathrm{kg}$ oileq $/ \mathrm{kWh}$ th & $4.58 \times 10^{-2}$ & $5.42 \times 10^{-2}$ & $4.62 \times 10^{-2}$ \\
\hline
\end{tabular}




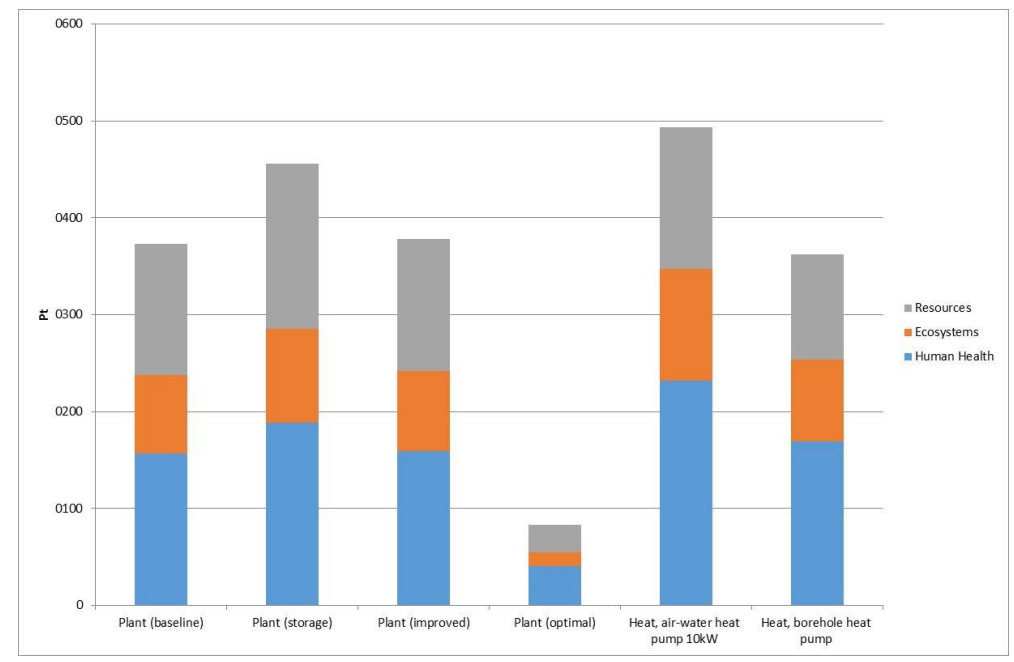

Figure 4. Endpoint indicators of all the analyzed scenarios.

\section{Conclusions}

The LCA of an innovative GSHP system with upstream TS is presented. The aim of the study is to measure the environmental impact of the system at the midpoint and endpoint level. The existing prototype was designed to switch between two different working modes: conventional and alternative. For this reason, the LCA was divided into different scenarios: a baseline scenario (system working in conventional mode), a storage scenario (system working in alternative mode), and an improved scenario (a proposed upgrade of the storage scenario). The primary data used for the analysis, collected from on-site monitoring activities, were related to the materials incidence and the energy consumptions of the different system configurations. The LCI showed differences among the three scenarios in terms of energy efficiency (i.e., the COP), materials and construction. With respect to the baseline scenario, the storage scenario was characterized by a worse environmental performance because of the low COPs of the system. The best results were obtained with the improved scenario, for which the removal of the cylindrical heat exchangers increased the system's COP, and the measured environmental indicators were consistent with those of the baseline scenario. As an example, the climate change indicator of the three scenarios was $0.156 \mathrm{~kg} \mathrm{CO}_{2} \mathrm{eq} / \mathrm{kWh}_{\text {th }}$ (baseline), $0.187 \mathrm{~kg} \mathrm{CO}_{2} \mathrm{eq} / \mathrm{kWh}_{\text {th }}$ (storage), and $0.160 \mathrm{~kg}$ $\mathrm{CO}_{2} \mathrm{eq} / \mathrm{kWh}_{\mathrm{th}}$ (improved). A complete optimization of the system is also presented as the optimal scenario: the cylindrical heat exchangers are removed, a more efficient circulating pump is used for the $\mathrm{BH}$, and the electric consumptions of GSHPs are entirely covered by the photovoltaic plant. The results show an average decrease of the measured midpoint indicators of $60 \%$ with respect to the baseline scenario. Future developments of the present study will focus on further optimization of the system, on the basis of completely re-designed TS using PCMs, which allow for a strong reduction of the storage volume.

Acknowledgments: This work was supported by the Italian Ministry for the Environment.

Author Contributions: Emanuele Bonamente performed the LCA and supervised the analysis of the results. Andrea Aquino performed the data acquisition and supported the analysis of the results.

Conflicts of Interest: The authors declare no conflict of interest.

\section{References}

1. European Commission. COM (2011) 112 Final. Commission Communication. Roadmap to a Competitive Low Carbon Economy in 2050; European Commission: Brussels, Belgium, 2011.

2. European Commission. Draft Horizon 2020 Work Programme 2014-2015 in the Area of Secure, Clean and Efficient Energy; European Commission: Brussels, Belgium, 2015. 
3. Nolte, I.; Strong, D. Europe's Buildings under the Microscope; Buildings Performance Institute Europe: Bruxelles, Belgium, 2011.

4. Sartori, I.; Hestnes, A.G. Energy use in the life cycle of conventional and low-energy buildings: A review article. Energy Build. 2007, 39, 249-257. [CrossRef]

5. Cappello, M. Efficienza Energetica Degli Edifici; Grafill: Palermo, Italy, 2008.

6. ENEA-Agenzia nazionale per le nuove tecnologie, l'energia e lo sviluppo economico sostenibile. Strategia per la Riqualificazione Energetica del Parco Immobiliare Nazionale, Allegato 1; ENEA Report; ENEA: Rome, Italy, 2015.

7. Bonamente, E.; Pelliccia, L.; Merico, M.; Rinaldi, S.; Petrozzi, A. The Multifunctional Environmental Energy Tower: Carbon Footprint and Land Use Analysis of an Integrated Renewable Energy Plant. Sustainability 2015, 7, 13564-13584. [CrossRef]

8. Ma, Y.; Saha, S.C.; Miller, W.; Guan, L. Comparison of Different Solar-Assisted Air Conditioning Systems for Australian Office Buildings. Energies 2017, 10. [CrossRef]

9. Ghasemi-Fare, O.; Basu, P. Predictive assessment of heat exchange performance of geothermal energy piles. Renew. Energy 2016, 86, 1178-1196. [CrossRef]

10. Self, S.J.; Reddy, B.V.; Rosen, M.A. Geothermal heat pump systems: Status review and comparison with other heating options. Appl. Energy 2013, 101, 341-348. [CrossRef]

11. European Parliament. Directive 2009/28/EC of the European Parliament and of the Council of 23 April 2009 on the promotion of the use of energy from renewable sources and amending and subsequently repealing Directives 2001/77/EC and 2003/30/EC. In Official Journal of the European Union L 140; European Parliament: Bruxelles, Belgium, 2009; p. 47.

12. Shortall, R.; Davidsdottir, B.; Axelsson, G. Geothermal energy for sustainable development: A review of sustainability impacts and assessment frameworks. Renew. Sustain. Energy Rev. 2015, 44, 391-406. [CrossRef]

13. $\mathrm{Bu}, \mathrm{X} . ; \mathrm{Ma}, \mathrm{W} . ; \mathrm{Li}, \mathrm{H}$. Geothermal energy production utilizing abandoned oil and gas wells. Renew. Energy 2012, 41, 80-85. [CrossRef]

14. Bonamente, E.; Moretti, E.; Buratti, C.; Cotana, F. Design and monitoring of an innovative geothermal system including an underground heat-storage tank. Int. J. Green Energy 2016, 13, 822-830. [CrossRef]

15. Bonamente, E.; Aquino, A.; Cotana, F. A PCM Thermal Storage for Ground-source Heat Pumps: Simulating the System Performance via CFD Approach. Energy Procedia 2016, 101, 1079-1086. [CrossRef]

16. Environmental Management_Life Cycle Assessment-Priciples and Framework; ISO 14044; ISO: Geneva, Switzerland, 2016.

17. Environmental Management_Life Cycle Assessment_Requirements and Guidelines; ISO 14040; ISO: Geneva, Switzerland, 2016.

18. Finnveden, G.; Hauschild, M.Z.; Ekvall, T.; Guinée, J.; Heijungs, R.; Hellweg, S.; Koehler, A.; Pennington, D.; Suh, S. Recent developments in life cycle assessment. J. Environ. Manag. 2009, 91, 1-21. [CrossRef] [PubMed]

19. De Lieto Vollaro, R.; Calvesi, M.; Battista, G.; Evangelisti, L.; Botta, F. Calculation model for optimization design of low impact energy systems for buildings. Energy Procedia 2014, 48, 1459-1467. [CrossRef]

20. Moretti, E.; Bonamente, E.; Buratti, C.; Cotana, F. Development of innovative heating and cooling systems using renewable energy sources for non-residential buildings. Energies 2013, 6, 5114-5129. [CrossRef]

21. Moretti, E.; Barbanera, M.; Foschini, D.; Buratti, C.; Cotana, F. Energy and Environmental Performance Analysis of Biomass-fuelled Combined Cooling and Heating System for Commercial Building Retrofit: An Italian Case Study. Energy Procedia 2016, 101, 376-383. [CrossRef]

22. A Life Cycle Impact Assessment Method Which Comprises Harmonised Category Indicators at the Midpoint and the Endpoint Level. Available online: https://www.researchgate.net/publication/302559709_ReCiPE_ 2008_A_life_cycle_impact_assessment_method_which_comprises_harmonised_category_indicators_at_ the_midpoint_and_the_endpoint_level (accessed on 11 November 2017).

(C) 2017 by the authors. Licensee MDPI, Basel, Switzerland. This article is an open access article distributed under the terms and conditions of the Creative Commons Attribution (CC BY) license (http://creativecommons.org/licenses/by/4.0/). 